\section{アンリ・エー著 大橋博司訳}

意 識

( 2 巻；みすず書房，1969〜 71，計；507ページ)

原書は初版63年，改訂增補第二版68年，小放て方評 判がたかい精神医学の名著である。この種の書物では専 門語がしきりに出てくるので，信頼できる翻訳は門外漢 にとって実に有難い。

本書の緻密で多岐にわたる論旨を紹介するのは容易で ないが，基本的には二つの座標軸が設定されている。一 つは意識野の階層的秩序, も5一つは人格之しての自我 の構成である。私などが心得ていた精神病ないし神経症 に和んする従来の定石的な分類は，「外因性」「「内因性」, 「心因性」といった用語にしめされているょうに，はじ めから「原因」の所在を予想して区別を設けたう壳で, そこに症状の記述を盛りこむという形をとっていた。と ころが本書では精神病一般が「急性」と「慢性」に二分 され，それぞれ上述の二つの座標軸酒される。そして それらの症状が意識構造の解体や混乱に结かならないこ とから，それらに刘応びけて意識存在の力動と構造をと らえよう，というのゔ全体のねらいである。

「意識䑐」というのは，たんなる意識内容のひらがり や流れのことではなく，現に生きられている自分と世界 との組織化さ机た全体で方る。その棈造は, 経臨が処理 され秩序づ计られる仕方に掠らじ，いわば重直方向にい

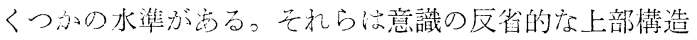
にたいして通常你ふさされている土台をなし，睡眠と覚

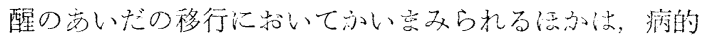
な楧造解体にむいてしふ現われてこない。最低層には， 欲求の力向づけという原初的な志向性にもとづく意味の

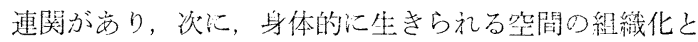
知覚による定立が竹こなわれ，第三に，時間的に秩序つ けら就た現在の把捉之自分の行為の自覚がなりたつ。こ れらの構造的諸水準が現実化されて初めてわれわれは自 分の意識野を自由に処理することができ，訟理的な思考 と実在への対応とが可能になる。

他方, この直接に生きられる経験の地平を超克, 特定 の誰かとして自我を構成する意識のはたらきがある。こ れは意識野の構成と相補的かつ分節的に結びつきなが ら，それとは別の方向性をもつ。慢性精神病の一般的特 徵は，意識が清明である場合でも，自我が自己自身を把
握しえず，自我と他者との関係が失調していることに市 る。それら自我の変容から柾外にいたる諸症状にてらし て，自我がそれとして統合される過程にもいくつかの局 面が区別されうる。第一に，身体をもつ自分を客体化市 るとともに，自分の内的思若を他のものふら切り離して とらえ, 次に, 世界を一つの全体的な洒值体系として問 題にし，第三に，自分をさまざまの役割の自己同一的な 主体としてひきうけ，最後に，自分の責任で固有の性格 を形成してゆく，という諸局面である。こうして現在の 状態や行動を超えてそれを包壁史性という力動的な存 在構造に颃いて，自我が人格として構成される。

著者はこれらの意識の諸相について，おびただしい臨 床上の所見を駆使しながらあらゆる觕度ふら解明し，玄 たいたるところで哲学者たちの洞察を援用することも忘 れない。神経生理学にも多くの紙数をさいているが，全 体をつうじて基調になっているのは，意識存在それ自体 の実在性に立脚する姿勢である。このことは特滛意識 の問題のとり㐫つかいに就いて示されている。というの は，意識を透明で完結的な最高法廷とみる古典的哲学に たいする反動として，無意裁のほうに主尊権を州し，そ こから心的生活を派生させるような考方方が一つの流行 ともなったが，著者はこれにははっきり反対する。意識 としてあるということは，みずから意識的になる渾動に ほかならず，之の意識の力動的防尿的構造と相関的に 「抑圧されたもの」として構成されるのが，フロイドが 正確にとらえた本来の意味での然意識であり，したがっ てこれは㐫くまで主体たる意㗀に従属し，意識のあり方 の諸相に抬うじた現われ方をする，というのである。同 様に，いわゆる構造主義にたいしても，それが特定の閉 じた系として客体化された鋳型のなかに人格的存在を埋 没させ，人間を殺すことになる，と難じている。

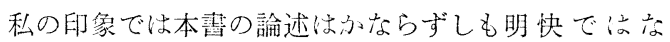
い:し和しそれは臨床的事実の劃和さと，関連支献の範 因の広さと，考えねばなら刚問題の深さと的らくること であらう。一般に精神病理学なるものが，理諭体系とし ては勿諭, 個々の用語や規定にいたるまで, 研究者のあ いだで定説も統一もできていない。しかしこれは科学と してスキャンダルだといってはなるない。むしろその 逆, 人間の問題の底知れなさを身をもってしめす労苦の 誇りともなろう。そして科学的知性にとって人間がいふ 
なるものとして現われるかという事態は，人間存在にと って科学が何を意味するかを考光させる焦点を，すなわ ち科学基礎論のもっとも根本的な問題点を, 構成するの では每るまいか。 (山本 信, 東大)

David K. Lewis,

\section{Convention: A Philosophical Study}

(Harvard University Press, 1969, 208 pages) 現に存在する言語的慣習は協約の産物である之いう見 解は確かに受入れ難いものである。すなわち会合におい てそのような協約が結ばれたといら歴史的事実がないか らである。しかしすべて慣習は協約の産物でしかあり光 ないといら前提のもとに次のような反論を企てることは 正しくない。その反論とはW. V.クワインや B.ラッ七 ル等が企てているもので，言語的慣習を成立させるため の協約はまだ成立していない言語（的慣習）によること はできないはずであるから，現化存在する言語的慣習は 協約の産物で㐫るといら見解を受入れることはできない といらものである。D.K.ルイスが本書において試みて いることは，慣習の起源は協約すなわらあからさまな同 意 (explicit agreement) でしか㐫りえないというさき の主張を否定し，あからさまな同意の概念に依存するこ となく慣習の概念を定義することである。さらにかくし て得られた慣習の概念を言語理論に適用することによっ て，クワインやM. ホワイトによって否定された分析的 真理と綜合的真理の区別を復活させることである。とい らよりるむしろ本書の動機から考党ると,クワインやM. ホワイトに答光るために摜習に関する研究が行われたと い光る。しかも慣習の新たな定義を得るための手段を与 立のはトマスC、シェリングの coordination 関する ゲーム理論で岉る。ルイスは本書の序文で「クワインお よびホワイトへの回答の手段を私に与光たのはトマス C.シェリングである。と述べている。（p.3）乙かし またそれ続けて「しかしながら結局はゲーム理論は足 場である。私はそれを用いず慣猊に関する私の分析を 述べなおすこことができる。とも述べている。したがっ て本聙に晾いてはそれぞれ互い関連をるつ三つのテー マについて考察されている。すなわち coordination に 関するゲーム理論, 慣習の概念, 分析的真理と綜合的真 理の区別である。

二人の者が互いに相手と会らことを欲していて，ぞこ で会うかは大した問題ではないとする。この場合同一の 場所へ二人が行くことが会うための必要十分条件であ る。二人は互いに相手の行く先を予測して自分の行く先
を決定する。このような相互依存的決断の問題の解決汅 は二つの要素が見られる。それは自分の願望（例えば相 手に会いたいといら願望）と相手の行動の予測（例えば 相手はどこそこへ行くだろらといら予測）である。そし て自分の願望は，相手がそこへ行くなら自分もそこへ行 きたいといら条件つきの願望を生む。このような事態を coordination problem という。そしてかかる事態がく り返し起る場合に認められる行為の規測正しさが慣習で 西る。かかる発想のもとにルイスによって与兄られる慣 習の概略的な定義は次のごとくである。

集団 $\mathrm{P}$ のメンバーがくり返し起る事態 $\mathrm{S}$ に拈ける行 為者であるとき，彼等の行為の規測正しさ (regularity） Rが慣習であるための必要十分条件は次のごとく である。

$\mathrm{P}$ のメンバー間のS Sいかなる場合にも，

(1) すべてのものがRに従い,

（2）すべての者が，すべての他者がR洋うことを 予測し，

(3) Sはcoordination problemであり，Rへの一様 な服従はS注ける coordination equilibrium であるが故に，すべての者が，他者がRに從う ことを条件にRに従うことを選ぶ（選好する）。

(1)は慣習を成立せしめる行為の事実であり，(2)は相互 の予測を，(3)快条件つき選好を(1)が伴っていることを要 求しているものである。要するに(2)拉よび(3)を根拠とし て(1)の決断が行われるといらことである。

ところで(2)の相互予測はなんらかの客観的な根拠をも つと考えられる。そこでルイスはかかる根拠となる上う な事態が成立していることが慣習成立の必要 条件と考 え，最初の定義を修正するのであるが，そのためにまず 常識 (common knowledge) を定義する。

かくかくのことが集団Pに括ける常識で出るた可の 必要十分条件は次のごとくである。

ある事態Aが成立していて，

(1) Pのすべての者が，Aが成立していると信じる 理由をもっている。

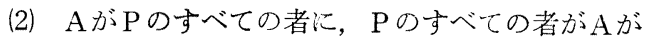
成立していると信じる理由をるっているという ことを暗示する。

(3) AがPのすべての者にかくかくのことを暗示す る。

以上のごとく常識を定義した上でルイスは先に述べた 概略的定義を修正する。先の概略的定義においては，P のメンバー間の S のいかなる場合にも(1)(2)(3)が真である ことが必要十分条件であったのであるが，修正された定 
義においては(1)(2)(3)が真であると同時にPにおける常識 であることが要求されている。しかしそれでも不十分で あるとルイスは考え，修正をかさねるのであるが，第二 回目の修正の要点は次の二点である。第一にルイスは唯 一の可能な慣習なるものは存在しないと考学る。そして

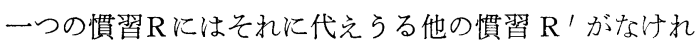
ばならないといら。そしてRを選ぶか $\mathrm{R}$ ‘を選ぶかは任 意のことであって，慣習は任意的であるといえるのはか かる意味においてである。かかる意味において慣習とは 本来任意のものであって任意の慣習といらいい方は重複 しているのである。そしてかりに任意でない慣習があっ たとしても，その慣習に従うのはそうすることが最善の 道だからであり，それに従わないことは戦略上の誤り (strategic error) である。第二の要点は慣習の程度の 考劣導入し，「すべての者」を「ほとんどすべての者」 によって置き代えたことである。こうしてルイスは最終 の定義に到達するのである。そしてその他の規則正しさ 一同意，社会的契約，規範，規則，模倣等による規則正 しさーと比較する。このうち, 問題の同意をルイスはど のように解釈しているかというと，慣垍を生み出すため の有力ではあるが単に一つの手段であると解 釈してい る。換言するならば，他者の行為の予測のための一つの 根拠である。

次に以上のごとき慣習の重要な実例として言語的慣習 をとりあげるのであるが，その予備段階として合図の問 題 (signaling problem) から始め, 言語による合図の 分析を経て，可能な言語 (possible language) の分析 に到達し，さらにめる可能な言語を実際の言語たらしめ るものは何かを考察することによって彼の目標一分析性 （analyticity）の概念の定義一に到達する。

ルイスが言語と呼んでいるのは解釈された言語 (interpreted language)であり，いわば言語と解釈の両方を 含むものである。しかも可能な言語は一つの解积ではな く一組の解釈を文に与える。さらに文の真理値は発言の 機会と相対的に決定される。。つまりある文は可能な言 語しにおいて，ある解釈のもとにある（発言の）機会に 真または為である。そしてただ一つの解釈が与えられる 場合文は明確で (unambiguous) あり，いかなる機会に も同じ一組の解釈が与兄られれば文は不変で (eternal) あるといわれる。そしていずれの場合にも真理条件が成 立するか否かはある可能な世界（発言が起る機会が位置 づけられている世界) においてのことである。ここでわ れわれはルイスの「可能な言語Lに打汁る分析性」なる 概念を定義することができる。

ある文 $\sigma$ が発言の機会 0 に拈いて $<\mu, \tau>$ なる解釈
のもとに分析的であるための必要十分条件は次のごと くである。

$L$ が $\langle\sigma, o>$ に $\langle\mu, \tau\rangle$ を含む一組の解釈を与光， 真理条件 $て$ がすべての可能な世界において成立する。 要するに分析性とはすべての可能な世界に第ける真理性 である。

さてルイスが言語の慣習というのはそれによって人の 集団Pがある可能な言語 Lを使用するもので市る。これ はルイスによって「Lに拈ける誠実さの慣習」と呼ばれ る。つまりLに拈いて誠実であることが慣習になってい るといらことである。Lにおいて誠実であるといらこと は，Lに含まれる文を時々発言することによって言葉を とりかわすことに参加し，Lにおいて真でないことを発 言しないように努めることである。ところで慣翼とは先 に指摘したように条件つき選好（他人がそうするなら自 分もそうするという選好）によって支持されるものであ るから，Lにおいて誠実であるといらことが慣習である のは，他人もそうすることを条件にそうすることが各人 の願望（すなわら伝達し合らこと）を満たすからそうし ている（Lにおいて誠実である）といらことである。

しからばかかる「しにおける誠実さの慣習」によって Lが実際の言語になった場合の分析性はどのように定義 されるだろらか。簡単にいえば先の可能な言語における 場合の分析性の定義に，Lが実際の言語であるといら条 件がつけ加えられるだけである。そこでごくおおまか に，実際の言語における分析性の概念の定義に含まれる 要点を述べると次のごとくであろう。われわれはそれぞ れ自分の思想を伝達したり他人の思想を伝達されたりし たいといら願望をもっていて，そのための手段となる言 語体系がいくつかあり，他人がそのらちの一つを使用す るといらことがある証拠によって示されており，その結 果各人が同一の言語を実際の言語として使用する。そし てとこに含まれるある文がいかなる世界で発言されてる 真である場合その文は分析的であるといわれるというこ とである。

雪は白いといらことを伝えるために，「雪は白い」発 言するか ‘Snow is white’ と発言するかは任意のこと である。(「白い」の代りに「赤い」と発言することさえ 任意のことである。）それなのに日本人はなぜ「雪は白 い」と発言するのか。これがわれわれのいだく素朴な疑 問である。われわれが言語的慣習はあからさまな同意の 産物だと感じるのはかかる意味においてである。ルイス によれば「雪は白い」と「雪は赫い」雪は白いといらこ とを伝えるための二つの可能な言語に属する文であり, われわれはどちらを選んでもよいのである。こういう意 
味においてはルイスも言語的慣習の任意性を認めている わけである。むしろそのよらな選択の余地が残されてい るところにこそ慣習が存在しらるのである。ルイスが考 察の対象としているのは，「雪恃白い」といら文を含む言 語を日本人が選択少る理由である。かかる選択は言語使 用者に一定の関心があり他人の選択に関する安定した予 測が可能であるかぎり任意のものではない。しかしこの ようなことを指摘することによって分析的であることと 綜合的であることの区別を復活させることができるであ ららか。ルイスは，分析的で市るとはすべての可能な世 界汅扮いて真であることで㘯ると主張する。かかる主張 はルイスを待たなくともライプニッツの理性真理の思想 のうちに見出される。さらにカルナップの，分析的であ るとはいかなる状態部述(state description)のもとでも 真であることといら定義とも本質的には差がない。クワ インが『経験主義の二つのドグマ』において指摘した， 分析的であることと綜合的であることの区別の困難さは 上のような定義のもとでも生じているのである。ところ がルイスはクワインの指摘しているのは可能な言語に打 汀る困難さではなく実際の言语汇拈行る区別の困難さで 方ると解して，一つの可能な言語を実際の言語たらしめ る条件を, 言語の使用といら行動の観点から提出してク ワインに答えようとしている。そのさいルイスは可能な 言語における分析性の概念泩明であると仮定している が，クロインは人工言語に扮いても区別の困難さをま奴 がれることはできないといっているのである。要するに ルイスの主張は, 一つの可能な言語において分析的な文 を見分けることは容易であり，可能な言語のうちどの言 語が実際に使用されているのかが分れば実際に使用され ている言語に执いて分析的な文を見分けることは可能で あり，いかなる言語が実際に使用されているかは誠実さ
の慣習の概念によって指摘されるはずで屴るから実際の 言語に沶いて分析的であることが何であるかは明らかで あるというものである。したがって根本的にはルイスは， 分析的であるとは意味論的規則のみによって真である ことであるという無意味な定義（クワインが否認してい る定義である) 代えて，すべての可能な世界に执いて 真であることであるという定義（やはりクワインが否認 している定義) を提出しているにすぎない。かかる主張 がクワインの壊疑に答えるためには，「可能な世界」な るものを明確にしなければならない。それには例兄ば可 能な世界とは一つの言語のモデルであるのか，そして現 在実際に使用されている英語に含まれる John is a bachelor' 飞真理值Tを与兄 'John is married' にも T を与光るような世界も可能な世界とい光るのか，もしそ らであるとするならば， ‘No bachelor is married’な る文はいかにして分析的であるといえるのか。このよう な問に答觉なければならない。ルイスは次のようにい う。「既婚の独身者之呼べる者が存在しないのは慣習に よる。しかし既婚の独身者がこの世界にもいかなる世界 にも存在しないのは慣習によるというなかれ。」現在使 用している言語に含まれる分析的に真なる文に真理値 T を与光るような世界のみが可能な世界であるという説明 は循環に陷るのみならず，言語的慣習によって世界の可 能性を見定めようとするのはよくない考光であるとルイ スはいら。結局彼は可能な世界についての十分な説明を 与えていない。可能な言語と実際の言語とを誠実さの慣 習によって橋渡しをしたことによってクワインやホワイ トの壤疑に答光光たとルイスが考光たのが不可解であ る。結局最初に述ベたルイスの三つのテーマは関連をも たない独立したテーマとして研究されたかのごとくであ る。

（黒川 喜正，近畿大） 